\title{
Problems of the Genesis \\ of the Academic Musical Culture of Krasnoyarsk (on the Methodology of Local History Studies)
}

Yevgenia S. Tsareva*

Krasnoyarsk State Institute of Arts

22 Lenin Str., Krasnoyarsk, 660049, Russia

Received 16.01.2017, received in revised form 24.07.2017, accepted 07.08.2017

The methodology of music and local history studies in the $21^{\text {st }}$ century is being significantly enriched and is mainly based on an interdisciplinary approach. A special body of work consists of works on the study of various components of the musical culture of Siberia - a vast region that is distinguished by the richest conglomerate of musical phenomena. This article observes the origin and development of academic musical traditions in one of the cities of Siberia - Krasnoyarsk - since the time of its foundation to the present days in their inseparable "genetic" connection with the spread and development of the European musical experience in the territory of the region. The analysis of mechanisms and forms of penetration of the latter required a cultural perspective and appeal to such concepts as "cultural diffusion", "culture translation channels", "cultural mediation", "cultural dialogue", etc. The article reveals a "tempo-rhythm" of the formation of the academic musical culture of Krasnoyarsk as a system, outlines its infrastructure and identifies the factors that contribute to these phenomena. Also, for the analysis of the local history material, the article addresses some ideas of A.A. Zinoviev's sociological theory "about the original cell". As a result, the author obtains new results in understanding the musical and historical processes in Krasnoyarsk.

Keywords: academic traditions, musical culture of European type, cultural diffusion, infrastructure of culture, cell, core, Krasnoyarsk.

The reported study was funded by Russian Foundation for Basic Research, Government of Krasnoyarsk Territory, Krasnoyarsk Region Science and Technology Support Fund to the research project №17-14-24006.

DOI: $10.17516 / 1997-1370-0134$.

Research area: art criticism.

In recent decades, in the Russian musicology the topics that traditionally relate to such a field as musical local studies and that are dedicated to studying musical history of the Russian province are getting actively developed. Various facets of musical culture of cities and regions are under the close attention of scientists. As stressed by I.V. Belonosova, the scientific community is interested in the issues related to "the consideration of music in its social existence (in particular, the study of functions of music in relation to other spheres of culture)", "the research of musical

(C) Siberian Federal University. All rights reserved

* Corresponding author E-mail address: evatcareva@gmail.com 
practices as socio-cultural institutions"; the issues that involve "certain structural components of musical culture (various types of musical activity, subjects of this activity, institutions supporting it, as well as cultural values created in the process of musical activity" (Belonosova, 2015: 83). Accordingly, the methodological apparatus is expanding and becoming more complex. Events and phenomena are increasingly being analyzed and different methods and concepts from various fields of the Humanities are introduced for their comprehension. In addition to traditional address to musicological, ethnographic, historical and historiographic studies, the local music studies actively involve insights in regional studies, cultural studies, sociology, anthropology, philosophy and other areas of the Humanities. The number of works based on an integrated, interdisciplinary approach is growing.

A special group of scientific research is the works on the study of the musical past and the modern realities of Siberia - a large region that undoubtedly has its place in the general field of Russia's cultural development, and also its specificity in the development of the musical historical process. In the Siberian territory, various national groups coexist and interact, and among them there are the indigenous peoples and migrants. The vast territory is a multidimensional musical and cultural system that, at the level of subsystems and elements, includes different phenomena, which, in particular, have different temporal and spatial characteristics. Among them, there is an intonational array of traditional music - folklore and oral professional creativity of the indigenous peoples and newcomers, and European-oriented written (compositional, opus) art.

If folklore and oral professional creativity of the indigenous peoples take their origins in the extreme antiquity (Duishenalieva, 2011), then the existence of traditional art of settlers is noted in the region from the end of the $16^{\text {th }}$ century (the time of the first Cossack crusades), and the elements of written musical culture begin to penetrate Siberia in the $17^{\text {th }}$ century. Heterogeneity distinguishes geographic localization of the phenomena of different cultural layers even in the context of the modern urban life in Siberia. Accordingly, their influence on the music space is different, not only in the diachronic, but also in the synchronous sections. For example, in the so-called Russian cities of the region - Omsk, Tomsk, Krasnoyarsk, Irkutsk - the leading positions in the formation of the phonosphere, which are inherent in traditional art at the initial historical stage, were gradually lost. From the $18^{\text {th }}$ to the $19^{\text {th }}$ century, the European type of culture has played an active dominant role in their musical space in its academic interpretation, and since the $20^{\text {th }}$ century in the increasingly assertive mass interpretation. According to B.A. Shindin, it is the "European type of culture" that is central and determining in a complex system of spiritual values" for such administrative entities of Siberia, and "all the multitude of other types of culture constitute an environment of this central field that is peripheral in essence and polycentric (poly-ethnic, polyconfessional, poly-...) in structure - which is the core of culture" (Shindin, 2011: 15-16). We can observe a different picture of the distribution of musical positions in the cities of the autonomous national republics of Siberia-Ulan-Ude, Yakutsk, Kyzyl, Abakan and others. Their cultural space "is represented by a two-vector parity of the European and the national" (Shindin, 2011: 18). As B.A. Shindin notes, this two-vector parity is multilayered. "It contains and correlates positions of cultures of the West and the East, Europe and Asia, secular and confessional, high and mass, oral and written cultures..." (Shindin, 2011: 18).

Siberian music studies have a fairly long way of scientific formation. L.L. Pyl'neva notes that the first mentions about the musical art of 
the Siberian region are contained in the notes of well-known travellers, local lore specialists and scientists of the $18^{\text {th }}$ and $19^{\text {th }}$ century (Pyl'neva, 2013: 16). The main stages in the history of studying the musical culture of Siberia fall on the $20^{\text {th }}$ century. At the beginning of the $21^{\text {st }}$ century, developments continue and reach a new stage. The musical phenomena that have various national, confessional, social accessories and refer to various types of cultural system (traditional creativity, academic art) act as subjects of numerous researches - from separate articles to monographs and dissertational works. At the same time, there is unevenness in their study, and we are talking not only about quantitative indicators, but also about methodological issues. This is especially evident in the comprehension of traditional and academic musical layers. L.L. Pyl'neva emphasizes that "the research schools have been formed in the field of traditional culture, whereas empirical and descriptive approaches predominate in relation to the academic culture of Siberia" (Pyl'neva, 2013: 32). It should be noted that in recent years, in musicology, this problem has been successfully solved. There are scientific works and $\mathrm{PhD}$ theses devoted to various areas of the academic musical culture of Siberia. They not only rely on a vast source base and introduce a lot of new documents and materials into scientific circulation, but also differ in new approaches to a number of traditionally solvable issues. The conceptual and methodological apparatuses of a wide variety of the Humanities are actively involved for a deeper analysis. Among such studies we can name the works of I.V. Belonosova, N.V. Pomortseva, A.N. Pronina, L.L. Pyl'neva (Belonosova, 2007; Pomortseva, 2013; Pronina, 2014; Pyl'neva, 2013).

In this article, the author turns to the problems of the genesis of the academic musical culture of one of the largest and oldest cities in Siberia - Krasnoyarsk. The analysis of local history material in a culturological way gives new results and opens wide prospects in understanding the musical historical processes taking place in the region.

Traditionally, many phenomena of musical culture are studied from the standpoint of the general scientific system approach that allows us to consider an object as a whole complex of interrelated elements. The main principle of this methodological direction of scientific knowledge is the simultaneous perception of the system as a single whole and as a subsystem for higher levels. A structure of the system is hierarchical and implies the subjection of elements of the lower level to higher-level elements. Each element performs its function in the system. The way they interact through certain relations forms a structure that, according to A.E. Voskoboinikov, is an internal mechanism expressing "the fundamental inseparability of elements and subsystems from each other and from the holistic system itself" (Voskoboinikov, 2013). In musicology, a definition of "musical culture" means a super complicated hierarchical system of relations, which, according to A.N. Sokhor, includes: "1) musical values created or preserved in a given society; 2) all types of activities for the creation, storage, reproduction, distribution, perception and use of musical values; 3 ) all subjects of such kind of activity, together with their knowledge, skills and other qualities that ensure its success; 4) all institutions and social institutions, as well as the tools and equipment that accompany this activity" (Sokhor, 1980: 62). Musical culture acts as a subsystem to higher-level categories - artistic culture, spiritual culture and culture of society as a whole, and at the same time it includes various system complexes. One of them forms the sphere of academic music.

At present Krasnoyarsk is a major cultural centre of Russia, which has an extensive system of musical academic traditions. Among its main 
components are the local professional academic executive organizations and collectives (Opera and Ballet Theatre and Musical Theatre, symphony and chamber orchestras, choirs, chamber ensembles), soloists, a three-stage system of professional music education, the Union of Composers, music science and criticism, an established audience. At the same time, Krasnoyarsk is one of the cities that is located in the geographical periphery of the country and has a relatively "young" history of the development of academic art with its ups and downs.

Academic traditions in the musical culture of Krasnoyarsk are based (due to their genesis) on the system of norms and patterns of the musical language and thinking that has developed in the European professional written art of the New Time, which, in the $20^{\text {th }}$ century, acquired global distribution, globality, recognition as a standard. With all the proximity of the essential content, the notions of academic musical culture and musical culture of the European type have certain differences that have been manifested especially dramatically in the last century with the development and increasing "offensive" of the mass musical culture that has also grown on the basis of the European experience. Academic music is an integral part of the European culture, but unlike the latter, it means a narrower sound space limited by high spiritual criteria, strict guidelines that determine the intonational array and presuppose the presence of a complex infrastructure necessary for its implementation.

The main typological features of the European musical system that determine functioning of the world academic art and distinguish it from other types of culture, are designated as follows: 1) the use of notation writing not only to fix existing works, but also to create the new ones; 2) personal composer creativity; 3 ) the presence of a system of musical communication (composerperformer-interpreter - listener); 4) co-operation and differentiation of sound production and musical-social activity within the given system. A central phenomenon of the new European musical model, its cultural and historical phenomenon that "permeates and pulls together the entire multilevel and multi-tiered system of cooperative musical activity" and does not "have direct analogies beyond the European professional tradition of the last centuries" is a "musical work" (Beniumov, 2012: 10). M.I. Beniumov emphasizes: "a musical work is what is created and fixed in the author's musical notation, edited and published in printed notations, learned and performed in front of the audience (or is recorded on a storage medium), perceived and stored in memory, comprehensively analyzed, studied and evaluated" (Beniumov, 2012: 10).

Returning to the concept of the infrastructure of culture used above, it should be noted that this term is often used in cultural studies. With its help, the totality of elements of the system and their interconnected functioning are indicated providing for the "conditions of the creation, preservation, translation and reproduction of cultural values, development of cultural life and creativity" (Bykova, Ryzhenko, 2002: 22). Accordingly, a complex of basic elements forms the internal infrastructure of the academic musical culture (system) ensuring "circulation" and development of musical values in the society. Among them there are academic composer's creativity, concert and theatrical performance, music education, as well as the audience, publication of musical literature, production of instruments and other related goods, material and technical objects (buildings of music theatres and concert halls, music stores), music criticism, musicology, cultural management bodies, etc. Using some ideas of the sociological theory of AA. Zinov'ev about the "initial cell (embryo)" as a building material of the system of public relations (Zinov'ev, 2006), the academic musical culture is 
considered as a complex "multicellular" organism, each cell of which is formed by the designated "set" of elements that is necessary to maintain its autonomous and self-sufficient existence, selfreproduction and, at the same time, embodying the possibility and potential for development and growth. The cell is not only a part of the whole, but is the whole itself at the micro level. The core of the cell, the system-forming centre that generates all of the above components, and the link, without which its functioning is impossible, are seen as the musical-creative human resources. It is the activity of a composer, a performer, a listener, a teacher, a musicologist, and if to continue, a music master, a music critic, etc., who can sometimes be presented both differentially and as one creative personality.

The origin and development of academic traditions in the musical culture of Krasnoyarsk were driven by the centuries-old process of expanding the range of functioning of the European musical system. The Russian musical culture was formed as an inimitable variant of the all-European and as one of the major world art phenomena. The periphery of Russia, including the Siberian cities, perceived the Western musical model mainly through the prism of the Russian variant. If at the initial historical stage, the musical culture of Krasnoyarsk was relatively homogeneous and mainly focused on traditional art, then the actively distributed pan-European academic musical traditions referring to a different type of thinking led to the heterogeneity of the urban cultural space. Along with the folklore existing in it, a block of academic art has been formed for several centuries. As a result, an independent academic music system was formed, while merging, as an organic component, into the unified cultural integrity of Krasnoyarsk complicating and enriching it.

The influence of one culture on another, as well as the spread of a culture of one type onto broad geographical areas, largely occurs through the mechanism of personal mediation. In Krasnoyarsk, we can observe two parallel ways of mastering the European musical experience: a direct one, where mediators were Europeans, and a mediated one, when the transfer of new musical traditions in an adapted and revised version was carried out by Russians. At the same time, representatives of the European part of Russia and immigrants from Europe often came to Siberian cities not by their own free will.

A "Tempo-rhythm" of the formation of the academic music system in provincial Krasnoyarsk was distinguished by dependence on migration impulses that moved creative forces from major cultural centres (cities of European Russia and Europe) to the periphery and thus performed the donor function. Thanks to the cultural activity of the "newcomers", cultural contacts between them and the local population, the formation of the musical and social environment, the transfer, adaptation, assimilation, acceleration and further development of traditions of academic music have occurred (and is still occurring). One of the main places among the processes contributing to these phenomena belongs to the cultural diffusion, which in modern science is defined as the spatial distribution, penetration and borrowing of cultural values, patterns, norms, ideals (Teoriia kultury, 2008). It is generally accepted that the cultural diffusion proceeds more actively with a personified contact. As I.V. Kucheruk notes, the process of cultural diffusions is continuous, as is the development of cultures, but under the influence of external, often political factors, the speed of diffusion movements can become weakened, "frozen" or increased (Kucheruk, 2007: 44).

The main mechanism of socio-cultural communication, intercultural interaction is a dialogue that can include a two-way information exchange and a one-way action. Iu.M. Lotman 
draws attention to such conditions of the dialogue when the first of its participants (the "transmitter") has a large store of memory (experience), and the second one (the "receiver") is interested in learning this experience (Lotman, 1992: 122). Under these conditions, the dialogue of culturalcreative migrant and Siberians first took place, more often it was unidirectional and was based on a special form of relations - "between a speaker of the text and the one who perceives it" (Kalganova, 2004: 10). Nevertheless, depending on the cultural level of the participants in the creative contact, both a response flow of information and equal communication - the exchange of artistic values, arose in the process of evolution of the musical communication of Siberia and, which is certainly necessary for the harmonious development of the musical culture of any society.

Formation of the academic traditions in Krasnoyarsk was largely due to centrifugal diffusion processes that spread norms and patterns of the all-European musical model, while concentrating in certain channels of information transmission, and began almost from the time the city was founded. The parish Krasnoyarsk (before 1822) was penetrated by elements of the European musical culture of the New Age mainly in the musical genres that were dominant for the Russian reality of that period - spiritual and military. Thus, among the first mentioned information channels were the military and Orthodox music spheres occupying a significant place in the cultural space of Siberian cities before the beginning of the $19^{\text {th }}$ century. Despite their limited artistic applications, but in the conditions of constant contact and synthesis with secular art, they enriched and developed the local musical life introducing and strengthening the academic traditions. At the same time, since the foundation of Krasnoyarsk (1628), there was a "selective" transfer of new traditions through their direct carriers (secular artists), which was established from the time of
Peter the Great to another powerful musical and cultural channel of transmission - secular musicmaking. This channel fulfilled the main systemforming functions in the development of the local independent model of academic art.

The active formation of the infrastructure of academic traditions begins to steadily show itself confidently in Krasnoyarsk, the capital of the Yenisei province, namely by the middle of the $19^{\text {th }}$ century. Amateur music-making is the dominant in the emergence of the local academic system. Having been initially spread in the domestic "elite" circle, it goes beyond the "salons", is established in public-concert manifestations, is gaining wide popularity among the citizens and is gradually acquiring organizationally fixed forms. The growing quantitative and qualitative indicators of musical amateurism were largely dictated by the general leading self-organizing principle of the socio-cultural development of Russia in the $19^{\text {th }}-$ early $20^{\text {th }}$ century. The impulse that went not from "above", from state decisions, but dictated by the initiative from "below", from the active and enlightened representatives of various class groups, launched powerful self-organization processes that resulted in the creation of all kinds of public associations (so-called meetings, societies, clubs) subsequently enjoying support of the authorities and acquiring officially fixed forms of existence. As a result, in the 1880 's, thanks to the activities of the Krasnoyarsk Music Circle and then the Society of Music and Literature Lovers, the city receives the basic components of the local academic musical culture: an amateur symphony orchestra, a secular choir, a number of chamber instrumental compositions are formed; the first opera performances are conducted by efforts of the Krasnoyarsk citizens, the works of local composers are created and immediately performed, and a stable audience is formed. The success of the amateur social movement in Krasnoyarsk is crowned by the first professional 
musical and educational institution - the Musical classes found in 1892, albeit for a short time. Simultaneously, as a result of local cultural and evolutionary processes, musical journalism is actively developing in the city and musical criticism is emerging. From the last third of the $19^{\text {th }}$ century the professional components of the academic system are being formed in Krasnoyarsk - the City Theatre (1874), secular creative teams, which provides a greater influx of musicians into the city. An increasing flow of tour artists to Krasnoyarsk is facilitated by the TransSiberian Railway (1895) and the construction of equipped concert halls.

The years from 1628 to 1914 are represented by a lengthy and event-sparse "preparatory" period, during which the elements of the academic musical culture of the city are gradually formed, constituting its adaptive local version. The first world war and the following powerful social "explosions" (revolutions and the Civil War) provoked mass centrifugal migration flows unprecedented in their scale in 1914-1922, which contained large musical and creative forces (including foreign prisoners of war, European allies of the White Guards, refugees, "forced" guest actors) and their unique intersection in the Siberian region. By that time the academic musical model of Krasnoyarsk already had the necessary potential for carrying out the active and productive socio-cultural interaction, a creative dialogue between Siberians, residents of the European part of Russia and Europe on its basis. In a short historical regime (8-9 years) there were concentrated diffusion processes that influenced the evolutionary development of virtually all the elements of the academic musical culture of the city - various types of instrumental, vocal and choral singing, special education, composer creativity, music criticism, audience, tool production.
The period from 1914 to 1922 , due to its eventual density and effectiveness, is a major culminating phase of the whole preceding formation of the academic system in Krasnoyarsk. The peak of the climax takes place in the first Soviet years (the early 1920's) in the city, when the People's Conservatory opens its doors and successfully functions in the conditions of the state interest and continuity of the previously set up processes. The musical traditions and values of European civilization transmitted throughout the centuries to Krasnoyarsk "took root" and became so entrenched by 1920 that they formed an integral complex of necessary elements of the academic musical culture - a cell - for the successful and harmonious further systemic evolutionary selfreproduction and development.

The remaining musical forces in Krasnoyarsk did not allow the destruction of the formed cell of the academic musical model. Their creative aspirations, activity, selfless work, a level of skill were the life-supporting, main element of the cultural system - its core. In the most difficult conditions, in the academic musical culture that was transferred by the state to the positions of self-support with the beginning of the NEP, its carriers activated the self-organization processes that enriched Krasnoyarsk with the most diverse forms of concert and musicaltheatrical performance. During the economic crisis, the mainstay of professionalism and the consolidating centre of the academic system was the People's Conservatory. Later these functions were also performed by the Labour Opera Group (1924-1925), the Krasnoyarsk Philharmonic Society (1929), the Regional Concert and Variety Bureau (1938). But the state prepared a terrible blow to the core of the musical culture not in the 1920 's, when it suspended the financing of its social institutions for a while, but in the second half of the 1930's, when the best music figures of Krasnoyarsk were repressed and shot. 
At the same time, the traditions of academic art built-in by the beginning of the Soviet period became the basis for their further evolutionary development. It took decades, the new creative impulses and migration culture flows (the creative collectives of the European part of Russia evacuated during the Second World War, major specialists exiled from the country's metropolitan area, artists who came to Siberia for professional allocation), the efforts of the authorities and the Krasnoyarsk musicians for the academic system of the city to survive another powerful culmination phase (the late 1970's - the early 1990 's) and reach a different qualitative level of its functioning.

Within two years (1977-1978) the city has established an opera and ballet theatre, a symphony orchestra, an art institute with three departments music, theatre and art. In 1978, the choreographic department of the Krasnoyarsk School of Arts founded two years earlier became an independent educational institution - a choreographic school. In 1982-1984, the Small and Large Concert Halls were built for the Philharmonic Hall, and a church with an installed organ was restored. In 1983, the Krasnoyarsk branch of the Union of Composers began its work. The impulses given at the end of the Soviet era and largely determined by the decisions of the authorities, despite the next change in the social formation in the country, had profound consequences. Once again, in the midst of a financial-vacuum situation for the music culture, the large creative forces in Krasnoyarsk initiated active self-organizing processes, the results of which were subsequently supported by the new administration. In 1993, a whole galaxy of professional music performing organizations was established in the city - chamber, brass and folk orchestras, a male choir and a choral ensemble of soloists. A flow of music-promising young people from Krasnoyarsk wishing to improve professional knowledge has expanded its geography and focused not only on large centres of Russia, but also on Europe. The centripetal impulses formed in the city were fully involved in the development of the world academic musical culture. Modern Krasnoyarsk already as a new centre of Siberia also rises to a different evolutionary stage and acquires its own periphery. The centrifugal impulses coming from the city have an impact not only on the distribution and development of academic traditions in the territory of the Krasnoyarsk Territory, but also have a direct strong influence on the musical culture of the neighbouring republics - Khakassia and Tyva.

\section{References}

Belonosova, I.V. (2007). Muzykal'naia kul'tura Chity [Musical culture of Chita]. Krasnoyarsk. 167 p.

Belonosova, I.V. (2015). Muzykal'noe kraevedenie v nachale XXI stoletiia [Musical local history at the beginning of XXI century]. In Privolzhskii nauchnyi vestnik [Volga Scientific Herald], 4-2 (44), $82-84$

Beniumov, M.I. (2012). Khudozhestvennye sredstva muzykanta-ispolnitelia: paradoks ponyatiia, istoricheskii genezis, struktura, funkcii [Art funds performing musician: the paradox of the concept, historical genesis, structure, functions]. Krasnoyarsk. 140 p.

Bykova, A.G., Ryzhenko, V.G. (2002). Kul'tura Zapadnoi Sibiri: istoriia i sovremennost' [Culture of Western Siberia: Past and Present]. Omsk. 372 p.

Duishenalieva, K.S.(2011). Tiurkskaia muzykal'naia kul'tura v svete evoliutsii kul'turologicheskikh traktovok muzyki kak sotsial'no-tsivilizatsionnogo iavleniia [Turkic musical culture in the light of the 
evolution of cultural interpretations of the music as a social and civilizational phenomenon]. In Voprosy kul'turologii [The culturology issues], (5), 64-68.

Kalganova, V.A. (2004). Problema vzaimodeistviia zapadnoevropeiskoi i russkoi kul'tur rubezha XVII-XVIII vv.: filosofsko-kulturologicheskii aspekt [The problem of interaction of Western European and Russian cultures the 17-18 centuries: philosophical and cultural aspect]: Abstract of dissertation for the degree of candidate of philosophical sciences. Saratov. $30 \mathrm{p}$.

Kucheruk I.V. (2007). Kul'turnaia diffuziia v sovremennom mire i obrazovanii (na primere vzaimodeistviia russkoi i severoamerikanskoi kul'tur) [Cultural diffusion in today's world and education (by the example of the Russian and North American cultures)]. In Voprosy kul'turologii [The culturology issues], (3), 44-55.

Lotman, Iu.M. (1992). Stat'i po semiotike i topologii kul'tury [Articles on culture semiotics and topology]. Tallin. (1), $490 \mathrm{p}$.

Pomortseva, N.V. (2013). Razvitie akademicheskogo khorovogo ispolnitel'stva v kemerovskoi oblasti v kontekste muzykal'noi zhizni industrial'nogo regiona [Development of academic choral performance in the Kemerovo region (in the context of the musical life of the industrial region)]: Abstract of dissertation for the degree of Candidate of Art criticism. Novosibirsk. 24 p.

Pronina, A.N. (2014). Formirovanie organnoi kul'tury v Sibiri: XIX-pervaia tret'XXv. [Formation of the organ culture in Siberia: 19th - the first third of the 20th century]: Abstract of dissertation for the degree of Candidate of Art criticism. Novosibirsk. 24 p.

Pylneva, L.L. (2013). Protsessy stanovleniia tvorchestva kompozitorov Buriatii, Tyvy i Iakutii [The process of becoming creative composers of Buryatia, Tuva and Yakutia]. Novosibirsk. 476 p.

Shindin, B.A. (2011). Muzykal'naya kul'tura goroda v kontekste tipologicheskikh podkhodov [The musical culture of the city in the context of typological approach]. In Muzykal'naia kul'tura goroda kak khudozhestvennaia i sotsial'naia problema: materialy nauchno-teoreticheskoi konferentsii [The musical culture of the city as an artistic and social problems: materials of scientific-theoretical conference]. Novosibirsk, 5-20.

Sokhor, A.N. (1980). Voprosy sotsiologii i estetiki muzyki [Questions of sociology and aesthetics of music]. Leningrad. (1), $296 \mathrm{p}$.

Teoriia kul'tury: uchebnoe posobie [Theory of Culture: Textbook]. (2008). Edited by S.N. Ikonnikova, V.P. Bol'shakov. St. Petersburg, 592 p.

Tsareva, E.S. (2014). Muzykal'naia zhizn' Krasnoiarska ot istokov do 1922 goda: puti formirovaniia muzykal'noi kul'tury evropeiskogo tipa [Musical life of Krasnoyarsk from the beginnings until 1922: ways of formation of musical culture of the European type]. Krasnoyarsk. 368 p.

Voskoboinikov, A.E. (2013). Sistemnye issledovaniia: bazovye poniatiia, printsipy, metodologiia [Systems research: basic concepts, principles and methodology]. In Znanie. Ponimanie. Umenie [Languages. Understanding. Ability]. 6, available at: http://www.zpu-journal.ru/e-zpu/2013/6/ Voskoboinikov_Systems-Research.

Zinov'ev, A.A. (2006). Faktor ponimaniia [Factor understanding]. Moscow. 528 p. 


\title{
Проблемы генезиса академической \\ музыкальной культуры Красноярска \\ (к методологии краеведческих исследований)
}

\author{
Е.С. Царёва \\ Красноярский государственный институт искусств \\ Россия, 660049, Красноярск, ул. Ленина, 22
}

\begin{abstract}
Методология музыкально-краеведческих исследований в ХХІ столетии значительно обогащุается и преимущественно базируется на междисциплинарном подходе. Особый корпус работ составляют труды по изучению различных составляющих музыкальной культуры Сибири - обширного региона, отличающегося богатейшим конгломератом музыкальных явлений. В настоящей статье рассматривается зарождение и развитие академических музыкальных традиций в одном из городов Сибири - Красноярске - от времени его основания и до наших дней в их неразрывной «генетической» связи с распространением и освоением на территории региона европейского музыкального опыта. Анализ механизмов и форм проникновения последнего потребовал культурологического ракурса и обращения к таким понятиям, как «культурная диффузия», «каналь трансляиии культурыл», «культурное посредничество», «культурный диалог» и др. Выявляется «темпоритм» формирования академической музыкальной культуры Красноярска как системы, очерчивается её инфраструктура, обозначаются факторы, способствуюшие данным явлениям. Также для анализа краеведческого материала привлекаются некоторые идеи соииологической теории А.А. Зиновьева «об исходной клеточке». В итоге автор получает новые результаты в осмыслении музыкально-исторических процессов в Красноярске.
\end{abstract}

Ключевые слова: академические традиции, музыкальная культура европейского типа, культурная диффузия, инфраструктура культуры, клеточка, ядро, Красноярск.

Исследование выполнено при финансовой поддержке Российского фонда фундаментальных исследований, Правительства Красноярского края, Красноярского краевого фонда поддержки научной и научно-технической деятельности в рамках научного проекта №17-14-24006.

Научная специильность: 17.00.00-искусствоведение. 